\title{
DNA homology between siderophore genes from fluorescent pseudomonads
}

\author{
IRENE T. ROMBEL and IAIN L. LAMONT* \\ Department of Biochemistry, University of Otago, PO Box 56, Dunedin, New Zealand.
}

(Received 2 February 1991; revised 16 August 1991; accepted 16 September 1991)

\begin{abstract}
Many species of pseudomonads produce fluorescent siderophores involved in iron uptake. We have investigated the DNA homology between the siderophore synthesis genes of an opportunist animal pathogen, Pseudomonas aeruginosa, and three plant-associated species Pseudomonas syringae, Pseudomonas putida and Pseudomonas sp. B10. There is extensive homology between the DNA from the different species, consistent with the suggestion that the different siderophore synthesis genes have evolved from the same ancestral set of genes. The existence of DNA homology allowed us to clone some of the siderophore synthesis genes from $P$. aeruginosa, and genetic mapping indicates that the cloned DNA lies in a locus previously identified as being involved in siderophore production.
\end{abstract}

\section{Introduction}

The fluorescent pseudomonads are a major group of Gram-negative bacteria which are found in a range of ecological niches. Most species are found in soil or fresh water, and some are plant pathogens (for example, strains of Pseudomonas syringae) or are beneficial to plant growth (for example, strains of the $P$. putida- $P$. fluorescens group) (Kloepper et al., 1980). One species, $P$. aeruginosa, is able to cause infection of immunocompromised patients or cystic fibrosis patients (Bodey et al., 1983), and infection can be fatal. As a group, these bacteria are characterized by the production of watersoluble fluorescent yellow-green pigments called pyoverdines or pseudobactins, which are siderophores involved in iron uptake. These pigments consist of a chromophore joined to a short peptide; the chromophore is conserved between species whereas the exact nature of the peptide is species-specific, with differences reflecting specificities of uptake (Hohnadel \& Meyer, 1988). The very close similarities between pyoverdines from different species suggest that the siderophores (and by implication the genes involved in their synthesis) have evolved from a common ancestor.

The objective of the work described here was to investigate homologies between genes which are involved in synthesis of fluorescent siderophores by different species of Pseudomonas. Genes involved in siderophore synthesis have been cloned from the plant-

Abbreviation: EDDA, ethylenediamine-di(o-hydroxyphenylacetic acid). associated species $P$. syringae, $P$. putida, Pseudomonas sp. B10 and Pseudomonas sp. M114 (Loper et al., 1984; Marugg et al., 1985; Moores et al., 1984; O'Sullivan et al., 1990). Our approach was to use DNA hybridization to investigate homology between siderophore genes from three plant-associated species and those of the animal pathogen $P$. aeruginosa.

\section{Methods}

Bacterial strains, plasmids and growth conditions. The bacterial strains and plasmids used are listed in Table 1. Strains of Escherichia coli were grown in LB medium (Miller, 1972) and strains of Pseudomonas aeruginosa in Brain Heart Infusion Broth (Oxoid; $18.5 \mathrm{~g} \mathrm{l}^{-1}$ ) at $37^{\circ} \mathrm{C}$, with good aeration unless otherwise stated. Solid media used were nutrient agar (Oxoid) for $E$. coli and Brain Heart Infusion Broth solidified with agar $(2 \%, w / v$; Difco) for $P$. aeruginosa. Production of pyoverdine by $P$. aeruginosa strains was detected using King's B agar (King et al., 1954) supplemented as required with the iron-chelating agent ethylenediamine-di( $o$-hydroxyphenylacetic acid) (EDDA; $200 \mu \mathrm{g} \mathrm{ml}^{-1}$ ), and was quantitatively measured by growing the bacteria in succinate minimal medium (Meyer \& Abdallah, 1978) and spectrophotometric analysis of the culture supernatant. Media were supplemented with antibiotics at the following concentrations $\left(\mathrm{ml}^{-1}\right)$ : ampicillin, $50 \mu \mathrm{g}$; carbenicillin, $300 \mu \mathrm{g}$; chloramphenicol, $30 \mu \mathrm{g}$ for $E$. coli and $100 \mu \mathrm{g}$ for $P$. aeruginosa; streptomycin, $1 \mathrm{mg}$; and tetracycline, $12.5 \mu \mathrm{g}$ for $E$. coli and $20 \mu \mathrm{g}$ for $P$. aeruginosa. Tetracycline was used at $100 \mu \mathrm{g} \mathrm{ml}^{-1}$ in the gene disruption experiment.

DNA isolation, manipulation and analysis. Chromosomal DNA was prepared using the method of Marmur (1961). Cosmid and plasmid DNA isolation was done by the method of Ish-Horowicz \& Burke (1981). $\lambda$ DNA preparations were carried out using the method of Grossberger (1987). Enzymic manipulation and sub-cloning of DNA, and Southern analysis, were carried out using standard methods (Maniatis et al., 1982); during Southern analysis filters were washed at 
Table 1. Strains and plasmids

\begin{tabular}{|c|c|c|}
\hline $\begin{array}{c}\text { Bacterial strain } \\
\text { or plasmid }\end{array}$ & $\begin{array}{l}\text { Relevant genotype } \\
\text { and phenotype* }\end{array}$ & Reference \\
\hline $\begin{array}{l}\text { P. aeruginosa } \\
\text { OT11 } \\
\text { OT373 } \\
\text { OT2021 } \\
\text { OT2021(RP1) } \\
\text { PAO307 } \\
\text { PAO4032 } \\
\text { PAO6232 }\end{array}$ & $\begin{array}{l}\text { leu-1 pro-1 } \mathrm{Pvd}^{+} \\
\text {leu-1 lys-1 }(\mathrm{RP} 1) \mathrm{Pvd}^{+} \\
\text {leu-1 pro-1 pvd::pSUP202 } \mathrm{Tc}^{\mathrm{R}} \mathrm{Cm}^{\mathrm{R}} \\
\text { leu-1 pro-1 pvd::pSUP202 (RP1) } \mathrm{Tc}^{\mathrm{R}} \mathrm{Cm}^{\mathrm{R}} \mathrm{Km}^{\mathrm{R}} \mathrm{Cb}^{\mathrm{R}} \\
\text { argC54 } \mathrm{Pvd}+ \\
\text { catAl mtu-9002 tyu-9030 met-9020 } \mathrm{Pvd}^{+} \\
\text {catAl mtu-9002 tyu-9030 } \mathrm{Pvd}^{+}\end{array}$ & $\begin{array}{l}\text { Laboratory stock } \\
\text { Laboratory stock } \\
\text { This study } \\
\text { This study } \\
\text { Haas } \text { et al. (1977) } \\
\text { Matsumoto et al. (1981) } \\
\text { Hohnadel et al. (1986) }\end{array}$ \\
\hline $\begin{array}{l}\text { E. coli } \\
\text { JM83 } \\
\text { S17-1 } \\
\text { NM539 }\end{array}$ & $\begin{array}{l}\Delta(\text { lac-proAB) lacZ } \Delta \mathrm{M} 15 \\
\text { hsdR HsdM } \mathrm{M}^{+} \operatorname{rec} A \text { integrated } \mathrm{RP} 4-2-\mathrm{Tc}^{\mathrm{R}}:: \mathrm{Mu} \mathrm{Km}^{\mathrm{R}}:: \mathrm{Tn} 7 \\
\text { supF hsdR }(\mathrm{P} 2 \operatorname{cox} 3)\end{array}$ & $\begin{array}{l}\text { Yanish-Perron et al. (1985) } \\
\text { Simon et al. (1983) } \\
\text { Frischauf et al. (1983) }\end{array}$ \\
\hline $\begin{array}{l}\text { Plasmids } \\
\text { pUC9 } \\
\text { pSUP202 } \\
\text { pMA1 } \\
\text { pMA3 } \\
\text { pJLM3A } \\
\text { pJLM300 } \\
\text { pSFL10 } \\
\text { pSFL11 } \\
\text { pSFL12 } \\
\text { pSFL14 }\end{array}$ & 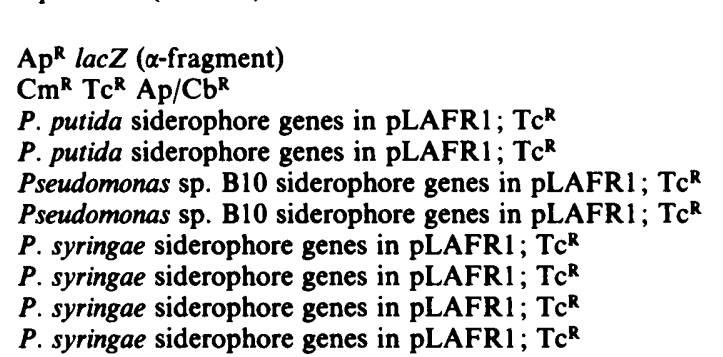 & $\begin{array}{l}\text { Vieira \& Messing (1982) } \\
\text { Simon et al. }(1986) \\
\text { Marugg et al. }(1985) \\
\text { Marugg et al. }(1985) \\
\text { Moores et al. }(1984) \\
\text { Magazin et al. }(1986) \\
\text { Loper et al. }(1984) \\
\text { Loper et al. }(1984) \\
\text { Loper et al. }(1984) \\
\text { Loper et al. }(1984)\end{array}$ \\
\hline
\end{tabular}

* Abbreviations: Ap, ampicillin; $\mathrm{Cb}$, carbenicillin; $\mathrm{Cm}$, chloramphenicol; $\mathrm{Km}$, kanamycin; Pvd, pyoverdine; Tc, tetracycline.

low $\left(50^{\circ} \mathrm{C}\right)$, medium $\left(55\right.$ or $\left.60^{\circ} \mathrm{C}\right)$ or high $\left(65^{\circ} \mathrm{C}\right)$ stringency, as appropriate. Restriction enzymes were purchased from Amersham, T4 DNA ligase from Promega, and calf-intestinal phosphatase from Boehringer-Mannheim. A library of $P$. aeruginosa genomic DNA was prepared in the cloning vector $\lambda \mathrm{EMBL} 3$ (Frischauf et al., 1983) following partial digestion of the $P$. aeruginosa DNA by Sau3A and size-fractionation of DNA using a sucrose gradient (Frischauf, 1987). DNA probes were labelled with [ $\left.{ }^{32} \mathrm{P}\right] \mathrm{dATP}$ using the oligonucleotide priming method (Feinberg \& Vogelstein, 1983) and were used to screen DNA which had been transferred to Hybond $\mathrm{N}^{+}$(Amersham) using the method recommended by the manufacturer.

Genetic manipulations. Cells of $E$. coli were transformed with plasmid DNA using the standard $\mathrm{CaCl}_{2}$ method (Dagert \& Ehrlich, 1979). Plasmids to be introduced into $P$. aeruginosa were first transformed into E. coli strain S17-1 (Simon et al., 1983). This strain contains a derivative of plasmid RP4 located in its chromosome, and the tra gene products of the integrated plasmid can cause conjugative transfer of plasmids carrying the RP4 oriT (mob) site into recipient bacteria. Conjugation was carried out using membrane filters as described by Willetts (1984). $P$. aeruginosa strains to be used as recipients in conjugation were grown overnight at $43^{\circ} \mathrm{C}$ without aeration in Brain Heart Infusion Broth containing potassium nitrate $(0.4 \%, w / v)$, diluted into Brain Heart Infusion Broth, and grown with aeration at $37^{\circ} \mathrm{C}$ until the $A_{600}$ was between 1.0 and 1.5 . The culture was then placed in a waterbath at $50{ }^{\circ} \mathrm{C}$ for $4 \mathrm{~min}$. This procedure partially inactivates the restriction system present in the bacteria (Holloway, 1965; P. Rainey \& $\mathrm{T}$. Merriman, personal communication), thereby increasing the number of transconjugants.

\section{Results}

\section{Hybridization of $P$. aeruginosa DNA with cloned siderophore genes}

We first investigated the possibility that $P$. aeruginosa contains DNA which is homologous to siderophoresynthesizing genes of other fluorescent pseudomonads. Genes involved in siderophore synthesis have been cloned from $P$. syringae, $P$. putida, Pseudomonas sp. B10 and Pseudomonas sp. strain M114 (Loper et al., 1984; Marugg et al., 1985; Moores et al., 1984; O’Sullivan et al., 1990). DNA was prepared from $P$. aeruginosa and Southern analysis was carried out using the cloned siderophore genes from $P$. putida and Pseudomonas sp. B10 as probes. The results of one such experiment are shown in Fig. 1. They clearly show that the probes hybridized to $P$. aeruginosa DNA. The two probes gave very similar results, with each hybridizing to several fragments of $P$. aeruginosa DNA. For the $P$. putida clone pMA3, it has been shown that all of the cloned DNA is involved in siderophore metabolism (Marugg et al., 1989) so that hybridization is not due to genes encoding other functions which are present in the clone. 


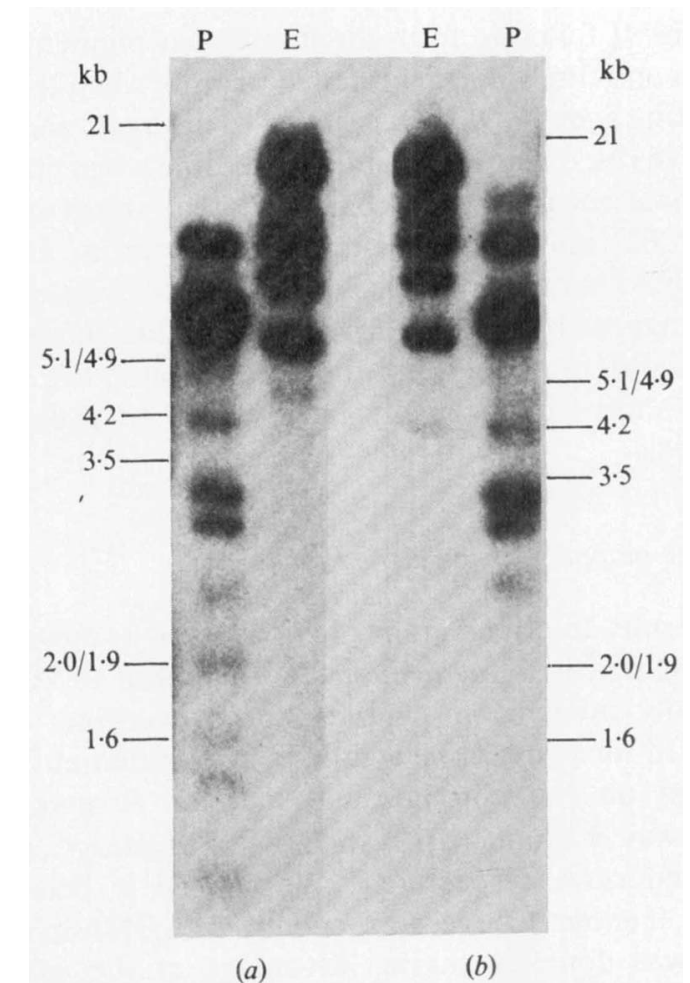

Fig. 1. Southern analysis of genomic DNA from $P$. aeruginosa. Genomic DNA from $P$. aeruginosa was digested with $E$ coRI (E) or PstI (P), electrophoresed and transferred to a nylon membrane. The DNA was then probed with $(a)$ pMA3 which contains siderophore synthesis genes from $P$. putida, or $(b)$ pJLM300 which contains siderophore synthesis genes from Pseudomonas sp. B10. The filters were washed under conditions of medium stringency $\left[60^{\circ} \mathrm{C}, 0.1 \times \mathrm{SSC}(1 \times \mathrm{SSC}\right.$ is $150 \mathrm{~mm}-\mathrm{NaCl}, 15 \mathrm{~mm}$-sodium citrate)]. The positions of marker bands are shown.

\section{Cloning of hybridizing $P$. aeruginosa DNA}

The probes used in the Southern analysis of genomic $P$. aeruginosa DNA contained genes involved in synthesis of fluorescent siderophores. We expected that the $P$. aeruginosa DNA hybridizing with the probes contained genes involved in the synthesis of pyoverdine, the fluorescent siderophore produced by $P$. aeruginosa. To test this possibility, and to allow us to further investigate hybridization between DNA from the different species, we cloned a portion of the hybridizing $P$. aeruginosa DNA. A library of $P$. aeruginosa DNA was prepared in a $\lambda$-based cloning vector, EMBL3 (Frischauf et al., 1983). Approximately 5000 clones were transferred onto nylon membrane and probed with radio-labelled pMAI DNA, which contains siderophore synthesis genes from $P$. putida (Marugg et al., 1985). One clone which hybridized strongly with the prohe was isolated and analysed further. This clone was named $\lambda$ OT1. A physical map of this clone is shown in Fig. 2.

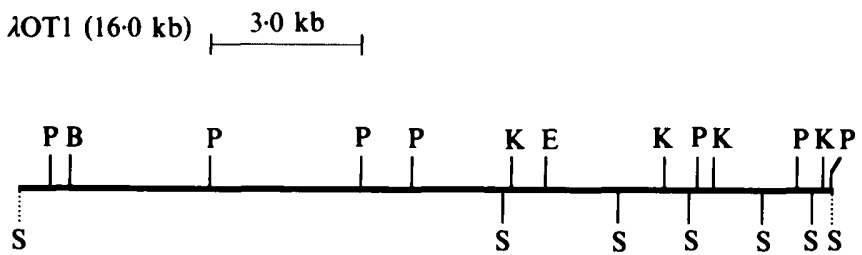

Fig. 2. Physical map of $\lambda O T 1$. $\lambda O T 1$ is a clone of DNA from $P$. aeruginosa which hybridizes with cloned siderophore genes from other fluorescent pseudomonads. Sites for BamHI (B), EcoRI (E), KpnI (K), PstI (P) and SalI (S) were mapped. The cloned DNA does not have restriction sites for Bg/II, HindIII, SacI or XbaI. The SalI sites at the ends of the DNA are in the cloning site of the EMBL3 vector and represent the boundaries of the cloned DNA. The $3.0 \mathrm{~kb}$ Pstl fragment used in the chromosomal disruption experiment (see text) is indicated.

The six $S a l l$ fragments present in $\lambda \mathrm{OT} 1$ were subcloned into pUC9 (Vieira \& Messing, 1982). They were then used as probes in Southern analysis of the cloned genes from $P$. syringae, $P$. putida and Pseudomonas sp. B10, with filters being washed in $0.2 \times \mathrm{SSC}$ at $55^{\circ} \mathrm{C}$ following hybridization. Similar results were obtained with all three species. The two central Sall fragments and the small right-most SalI fragment in $\lambda$ OT1 (Fig. 2) did not hybridize to the cloned DNA from the other species; the other SalI fragments did hybridize, with the largest (leftmost) fragment hybridizing with several fragments from each species (results not shown). These results confirmed that cloned $P$. aeruginosa DNA present in 2OT1 hybridized with siderophore-synthesizing genes from the other three species.

\section{Involvement of the cloned DNA in pyoverdine synthesis}

DNA present in clone $\lambda$ OT1 hybridized with DNA from $P$. putida, Pseudomonas sp. B10 and $P$. syringae which is involved in the synthesis of siderophores by these species. We therefore expected the $P$. aeruginosa DNA in $\lambda O T 1$ to be involved in synthesis of pyoverdine, which is chemically similar to the siderophores made by the plantassociated species (Hohnadel \& Meyer, 1988). The strategy used to test this involved disruption in $P$. aeruginosa of the chromosomal locus corresponding to the cloned DNA, followed by examination of the phenotypes of the resulting bacteria. The $3.0 \mathrm{~kb}$ PstI fragment present in $20 T 1$ (Fig. 2) was sub-cloned into the PstI site of plasmid pSUP202 (Simon et al., 1983), which was then mobilized from $E$. coli S17-1 into $P$. aeruginosa OT11. As the plasmid cannot replicate in $P$. aeruginosa, selection for the $\mathrm{Cm}^{\mathrm{R}}$ and $\mathrm{Tc}^{\mathrm{R}}$ markers carried by the plasmid gave rise to strain OT2021 in which the plasmid had become integrated into the $P$. aeruginosa chromosome by homologous recombination between the cloned PstI fragment and the chromosome. 
(a)

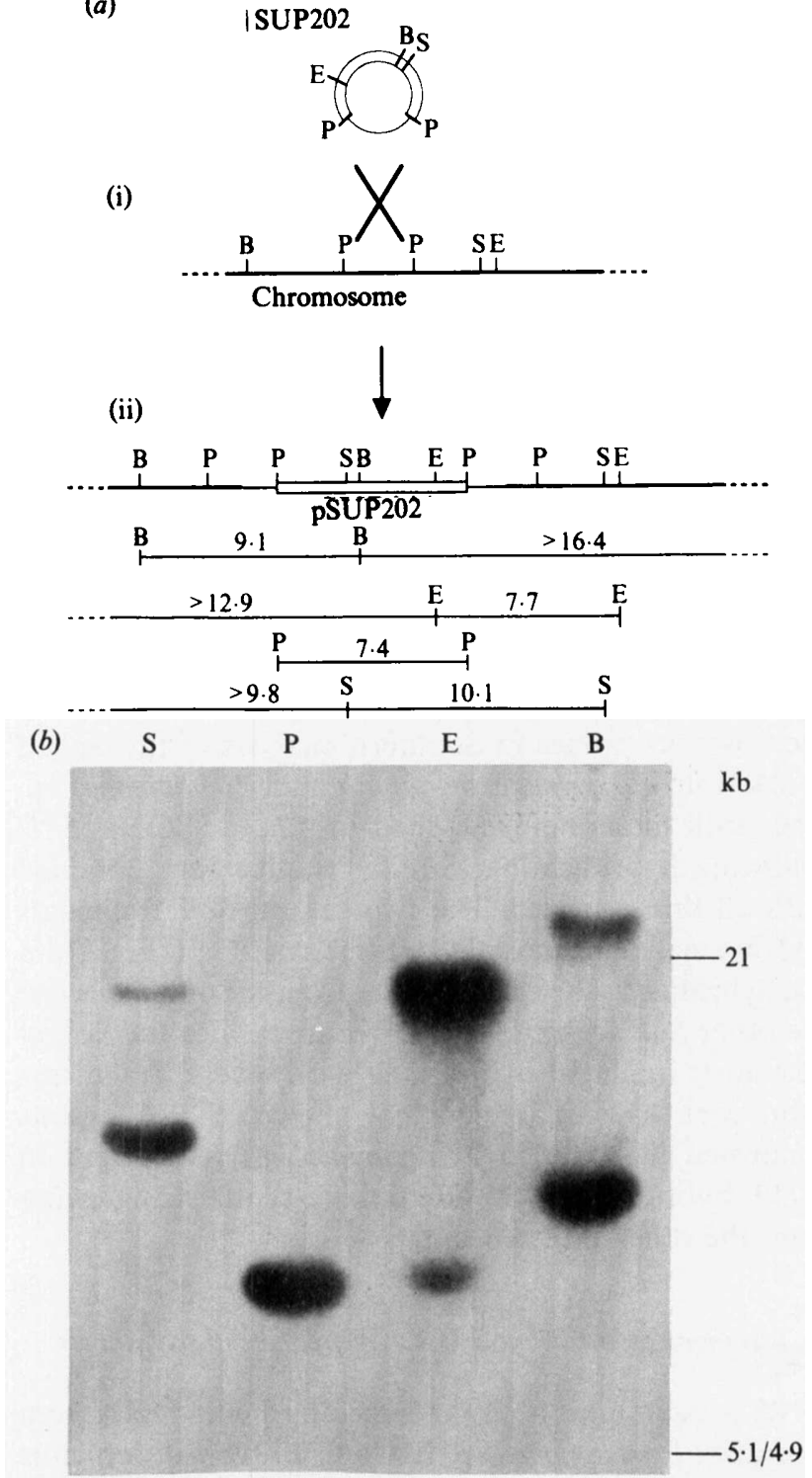

Fig. 3. Disruption of the cloned locus in $P$. aeruginosa. (a) Homologous recombination between the chromosome of $P$. aeruginosa and a $3.0 \mathrm{~kb}$ fragment of cloned DNA in plasmid pSUP202 (i) gave rise to strain OT2021 in which the pSUP202 DNA is integrated into the chromosome at the site of recombination and the $3.0 \mathrm{~kb}$ fragment has been duplicated (ii). Relevant restriction sites were identified from the restriction maps of $\lambda$ OT1 (Fig. 2) and pSUP202 (Simon et al., 1983). (b) Southern analysis of DNA from strain OT2021. Genomic DNA from strain OT2021 was digested with restriction enzymes EcoRI (E), BamHI (B), PstI (P) or Sall (S) and Southern analysis was carried out using pSUP202 as a probe. The sizes of the hybridizing fragments are 8.3 and $18.7 \mathrm{~kb}($ EcoRI), 9.9 and $25.5 \mathrm{~kb}$ (BamHI), $7.7 \mathrm{~kb}$ (PstI), and 10.7 and $17.3 \mathrm{~kb}(\mathrm{Sa} / \mathrm{I})$. These sizes are in agreement with the predicted sizes shown in $(a)$.

Southern analysis of genomic DNA from strain OT2021 confirmed that the expected recombination event had taken place (Fig. 3).

Unlike the parental strain OT11, strain OT2021 was unable to synthesize pyoverdine as determined by several criteria. It failed to form the fluorescent pigment when grown on King's B agar; it failed to grow when the ironchelating agent EDDA was added to the agar; and it did not give rise to any detectable pyoverdine when grown in succinate medium. We concluded that integration of pSUP202 into the chromosome in strain OT2021 prevented synthesis of pyoverdine, and as integration had occurred by homologous recombination between the cloned PstI fragment and the chromosome, the cloned DNA must also normally be involved in pyoverdine synthesis.

\section{Genetic mapping of the cloned locus}

The results described in the previous section showed that the segment of $P$. aeruginosa DNA present in $\lambda \mathrm{OT} 1$ is normally involved in synthesis of pyoverdine. Genes required for pyoverdine synthesis are located at 23 and $47 \mathrm{~min}$ on the chromosomal map of $P$. aeruginosa (Holloway \& Zhang, 1990) and are linked to $\arg C$, and to $m t u$ and cat $A$, respectively. We wished to determine which, if either, locus corresponded to the DNA in $\lambda O T 1$. This was done by taking advantage of the mob site present in pSUP202 and which was integrated into the chromosome at the cloned locus in strain OT2021. In the presence of the tra gene products of plasmid RP1 this site could act as an origin of chromosomal transfer during conjugation of OT2021 with recipient strains. The use of chromosomally integrated origins of transfer for gene mapping is well established in P. aeruginosa (O'Hoy \& Krishnapillai, 1987). Plasmid RP1 was introduced into strain OT2021 from strain OT373 by conjugation. Strain OT2021(RP1) was then used as a donor in crosses with appropriate recipient strains, selecting for transfer of the $\arg C$, met-9011, cat $A$ and $m t u$ markers. The results are summarized in Table 2 . The cat $A$ marker was transferred at a high frequency and $\arg C$ at a low frequency. This result shows that the integrated mob site in the chromosome of strain OT2021 is much more highly linked to the cat $A$ marker than to the $\arg C$ marker. As the mob site is present in the cloned locus, this indicates that the cloned DNA present in $20 T 1$ comes from the previously identified pyoverdine locus ( $p v d$ ), at $47 \mathrm{~min}$ on the $P$. aeruginosa chromosome which is close to the cat $A$ locus at 46 min (Hohnadel et al., 1986; Ankenbauer et al., 1986). The $m t u$ locus also lies in this region of the chromosome, at $48 \mathrm{~min}$, but is on the opposite side of the pvd locus to catA (Hohnadel et al., 1986; Ankenbauer $e t$ $a l ., 1986)$ so that failure to detect transfer of $m t u$ was because the orientation of mob in strain OT2021 resulted in $m t u$ being the last locus to be transferred during conjugation. The met-9011 marker was transferred at a frequency between those of $\operatorname{cat} A$ and $\arg C$ and this is consistent with its location between $\operatorname{cat} A$ and $\arg C$ on 
Table 2. Genetic mapping of the cloned locu.

Strain OT2021 (RP1) was used as a donor in conjugations with the recipients shown in the Table. The donor strain contained an origin-of-transfer site in the cloned locus. Selection for transconjugants was carried out on minimal medium, thereby selecting against donor and recipient bacteria. The frequency of transfer is expressed as the number of bacteria acquiring the selected marker divided by the number acquiring plasmid RPI from the donor strain; expressing the results in this way allows results from different crosses to be compared. The total number of transconjugants receiving RPI was between $1 \times 10^{6}$ and $4 \times 10^{6}$ in all three crosses.

\begin{tabular}{lcc}
\hline \hline Recipient strain & Selected marker* & Frequency of transfer \\
\hline PAO307 argC & $\mathrm{Arg}^{+}$ & $5.8 \times 10^{-5}$ \\
PAO4032 cat mtu tyu met & $\mathrm{Met}^{+}$ & $2.5 \times 10^{-3}$ \\
PAO6232 cat mtu tyu & $\mathrm{Cat}^{+}$ & $2.0 \times 10^{-2}$ \\
& $\mathrm{Mtu}^{+}$ & $<10^{-6}$ \\
& Tyu $^{+}$ & $<10^{-6}$ \\
\hline \hline
\end{tabular}

* Abbreviations: Arg, arginine utilization; Cat, catechol utilization; Met, methionine utilization; Mtu, mannitol utilization; Tyu, tyrosine utilization.

the genetic map (Holloway \& Zhang, 1990) and with the assignment of the cloned DNA to the pyoverdine locus near catA.

\section{Homology of $\lambda O T I$ DNA with siderophore-synthesizing genes}

The results described above showed that clone $\lambda O T 1$ contains DNA from $P$. aeruginosa which is involved in siderophore synthesis. We next wished to investigate the degree of homology of the cloned $P$. aeruginosa DNA with cloned siderophore genes from other species. The approach used was to carry out Southern analysis of the cloned DNA from three plant-associated species using the cloned DNA in $\lambda O T 1$ as a probe. Hybridization was initially carried out under conditions of low stringency, so that DNA fragments with relatively low homology were detected; the stringency was then gradually increased in order to identify the fragments which had most homology with the probe DNA. Typical results obtained under conditions of medium and high stringency are shown in Fig. 4. DNA from all three plantassociated species gave similar results, in that several DNA fragments hybridized with $\lambda O T 1$ DNA under conditions of low stringency and so must have some degree of homology to the $P$. aeruginosa DNA; at higher stringencies, hybridization only occurred for one or two fragments with each species, and these must have more extensive DNA homology. Some of the fragments did not hybridize with the probe even under conditions of low stringency indicating that homologous DNA was not present in $\lambda \mathrm{OT} 1$, or that the homology was too low to give detectable hybridization.

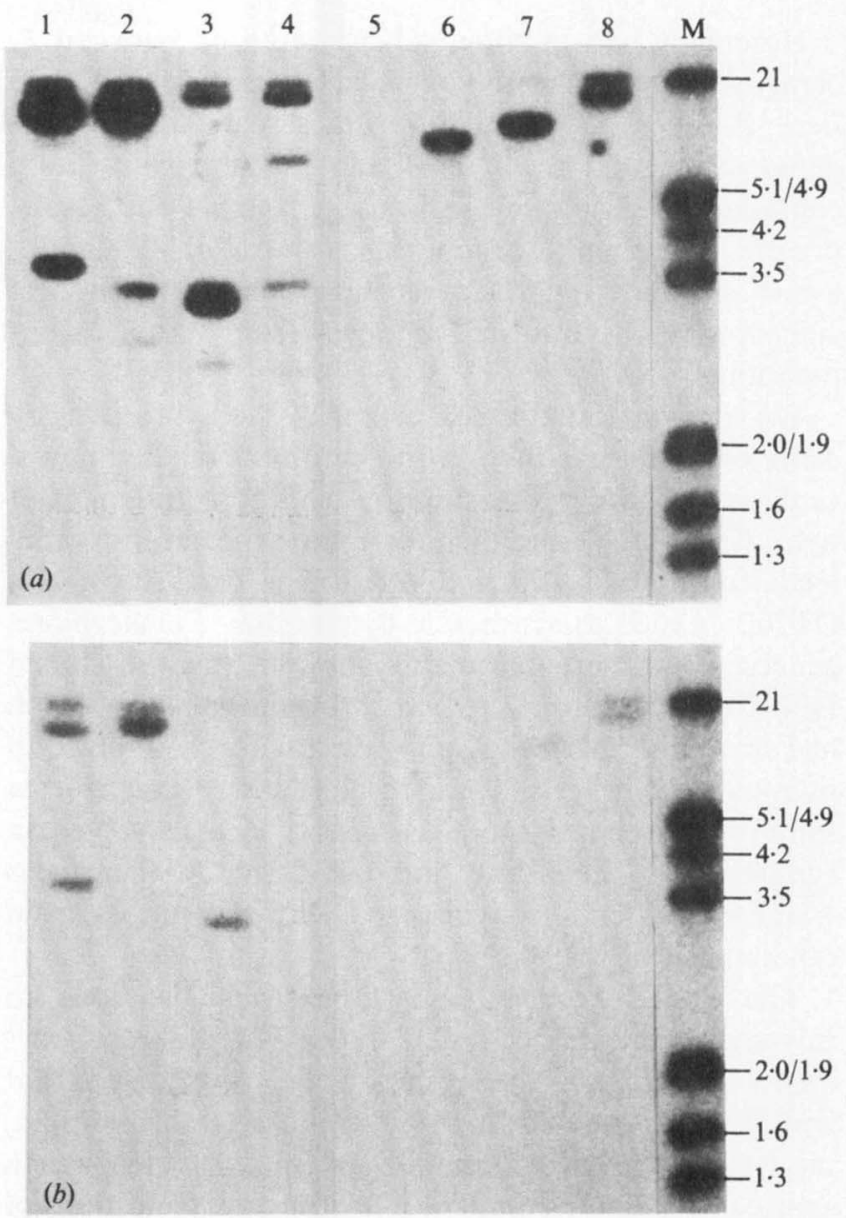

Fig. 4. Hybridization of $\lambda \mathrm{OT} 1$ with DNA from plant-associated pseudomonads. DNA from cosmid clones of siderophore genes from Pseudomonas sp. B $10(1,2), P$. putida $(3,4)$ and $P$. syringae $(5-8)$ was digested with EcoRI, electrophoresed and probed with insert DNA from clone $\lambda \mathrm{OT} 1$. Following hybridization, the filters were washed at $50,55,60$ and $65^{\circ} \mathrm{C}$ in $0.2 \times \mathrm{SSC}$, with autoradiography after each wash. (a) After washing at $55^{\circ} \mathrm{C}$ and $(b)$ after washing at $65^{\circ} \mathrm{C}$. Lanes: 1, pJLM300; 2, pJLM3A; 3, pMA3; 4, pMAl ; 5, pSFL14; 6, pSFL12; 7, pSFL11; 8, pSFL10; M, radiolabelled $\lambda$ DNA digested with EcoRI and HindIII.

\section{Discussion}

$P$. aeruginosa, an opportunistic animal pathogen, makes a fluorescent siderophore called pyoverdine which is chemically very similar to siderophores made by soil- and plant-associated pseudomonads. The experiments described here investigated the possibility that this similarity extends to the DNA level. The results show that there is extensive and strong homology of $P$. aeruginosa DNA with siderophore synthesis genes from at least three other pseudomonads, the plant pathogen $P$. syringae and the soil species $P$. putida and Pseudomonas sp. B10. This indicates that at least some of the DNA involved in siderophore synthesis has been conserved during the evolution of the fluorescent pseudomonads. 
Homology had previously been reported between $P$. aeruginosa DNA and the cloned $P$. syringae DNA used here (Lawson et al., 1986). Lawson et al. did not demonstrate that the hybridizing $P$. aeruginosa DNA contained siderophore synthesis genes, but the results presented here indicate that this is the case. We are not aware of other reports describing homology amongst siderophore synthesis genes from fluorescent pseudomonads.

We confirmed that at least some of the hybridizing $P$. aeruginosa DNA is involved in synthesis of the fluorescent siderophore pyoverdine by cloning a fragment of hybridizing DNA and then disrupting the chromosomal locus from which it was derived. The resulting strain, OT2021, failed to synthesize pyoverdine. Furthermore, genetic mapping experiments showed that the cloned DNA is derived from a region of the chromosome which had previously been shown to contain genes involved in pyoverdine synthesis. These results showed that at least some of the cloned DNA is from a locus involved in synthesis of pyoverdine and not from another locus which coincidentally hybridized with the probes from other species.

The cloned $P$. aeruginosa DNA was also used to investigate the degrees of homology of different fragments of DNA. The results (Fig. 3) showed that homology is not evenly distributed amongst the hybridizing fragments. A small number of fragments from each species were detected under hybridization conditions of high stringency, indicating a high degree of DNA sequence homology. Under less stringent conditions, more fragments were detected, and these must have lower (though still significant) sequence homology. The fact that different fragments show different degrees of homology presumably indicates that some genes involved in siderophore synthesis have been more highly conserved than others during the evolution of the fluorescent pseudomonads. This may be related to the functions of the genes. The chromophore moieties of the siderophores have been well conserved between the different species, so that it is likely that the relevant genes have also been highly conserved, whereas the small peptides which are attached to the chromophores show considerable evolutionary divergence (Hohnadel \& Meyer, 1988) which is likely to be reflected in divergence at the level of DNA sequence. Biochemical functions have not been assigned to cloned genes involved in siderophore synthesis from any of the species used in this study.

In summary, our results show that there is extensive homology between siderophore genes of $P$. aeruginosa and of plant-associated pseudomonads, and that different regions of DNA exhibit homology to differing extents, presumably reflecting the evolution of the DNA as the genes diverged from a common ancestor.
We are very grateful to Dieter Haas, John Leong, Joyce Loper, Reinhardt Simon and Peter Weisbeek for sending us strains and clones. We would also like to thank Andrew Shelling for his assistance in constructing the library of $P$. aeruginosa DNA. I. R. is a New Zealand Health Research Council Post-Graduate Scholar. This work was supported in part by a grant from the Otago Medical Research Foundation.

\section{References}

Ankenbauer, R., Hanne, L. \& Cox, C. D. (1986). Mapping of mutations in Pseudomonas aeruginosa defective in pyoverdin production. Journal of Bacteriology 167, 7-11.

Bodey, G. P., Bolivar, R., Fainstein, V. \& Jadeja, L. (1983). Infections caused by Pseudomonas aeruginosa. Reviews of Infectious Diseases 5, 279-307.

DAgerT, M. \& EhrLICH, S. D. (1979). Prolonged incubation in calcium chloride improves the competence of Escherichia coli cells. Gene 6, 23-28.

Feinberg, A. P. \& Vogelstein, B. (1983). A technique for radiolabelling DNA restriction endonuclease fragments to high specific activity. Analytical Biochemistry 132, 6-13.

Frischauf, A.-M. (1987). Digestion of DNA: size fractionation. Methods in Enzymology 152, 183-189.

Frischauf, A.-M., Lehrach, H., PoustKa, A. \& Murray, N. (1983). Lambda replacement vectors carrying polylinker sequences. Journal of Molecular Biology 170, 827-842.

Grossberger, D. (1987). Minipreps of DNA from bacteriophage lambda. Nucleic Acids Research 15, 6737.

HaAs, D. Holloway, B. W., Schambock, A. \& Leisinger, T. (1977). The genetic organization of arginine biosynthesis in Pseudomonas aeruginosa. Molecular and General Genetics 154, 7-22.

Hohnadel, D., HAAS, D. \& MEYER, J.-M. (1986). Mapping of mutations affecting pyoverdine production in Pseudomonas aeruginosa. FEMS Microbiology Letters 36, 195-199.

HohnADEL, D. \& MeYER, J.-M. (1988). Specificity of pyoverdinemediated iron uptake among fluorescent Pseudomonas strains. Journal of Bacteriology 170, 4865-4873.

HollowaY, B. W. (1965). Variations in restriction and modification of bacteriophage following increase of growth temperature of Pseudomonas aeruginosa. Virology 25, 634-642.

Holloway, B. W. \& Zhang, C. (1990). Pseudomonas aeruginosa PAO. In Genetic Maps. Locus Maps of Complex Genomes, 5th edn, pp. 2.712.78. Edited by S. J. O'Brien. Cold Spring Harbor, NY: Cold Spring Harbor Laboratory.

ISH-HOROWICZ, D. \& BURKE, J. F. (1981). Rapid and efficient cosmid vector cloning. Nucleic Acids Research 9, 2989-2999.

KING, E. O., WARD, M. K. \& RANEY, D. E. (1954). Two simple media for the demonstration of pyocyanin and fluorescin. Journal of Laboratory and Clinical Medicine 44, 301-307.

Kloepper, J. W., LeONG, J., Teintze, M. \& Schroth, M. N. (1980). Enhanced plant growth by siderophores produced by plant growthpromoting bacteria. Nature, London 286, 885-886.

Lawson, E. C., Jonsson, C. B. \& Hemming, B. C. (1986). Genotypic diversity of fluorescent pseudomonads as revealed by Southern hybridization analysis with siderophore-related gene probes. In Iron, Siderophores and Plant Diseases, pp. 315-329. Edited by T. R. Swinburne. New York: Plenum Press.

Loper, J. E., Orser, C. S., Panopoulos, N. J. \& Schroth, M. N. (1984). Genetic analysis of fluorescent pigment production in Pseudomonas syringae pv. syringae. Journal of General Microbiology 130, $1507-1515$.

Magazin, M. D., Moores, M. C. \& Leong, J. (1986). Cloning of the gene coding for the outer membrane receptor protein for ferric pseudobactin, a siderophore from a plant growth-promoting Pseudomonas strain. Journal of Biological Chemistry 261, 795-799.

Maniatis, T., Fritsch, E. F. \& SambrooK, J. (1982). Molecular Cloning: A Laboratory Manual. Cold Spring Harbor, NY: Cold Spring Harbor Laboratory.

MARMUR, J. (1961). A procedure for the isolation of deoxyribonucleic acid from micro-organisms. Journal of Molecular Biology 3, 208-218. 
Marugg, J. D., van Spanje, M., Hoekstra, W. P. M., Schippers, B. \& WEISBEEK, P. J. (1985). Isolation and analysis of genes involved in siderophore biosynthesis in plant-growth-stimulating Pseudomonas putida WCS358. Journal of Bacteriology 164, 563-570.

Marugg, J. D., DeWeger, L. A., Neilander, H. B., Oorthuizen, M., Recourt, K., Lugtenberg, B., van Der Hofstad, G. A. J. M. \& WIESBEEK, P. J. (1989). Cloning and characterization of a gene encoding an outer membrane protein required for siderophoremediated uptake of $\mathrm{Fe}^{3+}$ in Pseudomonas putida WCS358. Journal of Bacteriology 171, 2819-2826.

Matsumoto, H., Nakazawa, T., Ohta, S. \& Terawaki, Y. (1981). Chromosomal locations of $c a t A, p o b A, p c a A, d c u$ and $c h u$ genes in Pseudomonas aeruginosa. Genetical Research 38, 251-266.

MEYER, J. M. \& ABDALlaH, M. A. (1978). The fluorescent pigment of Pseudomonas fluorescens: biosynthesis, purification and physicochemical properties. Journal of General Microbiology 107, 319-328.

MILLER, J. H. (1972). Experiments in Molecular Genetics. Cold Spring Harbor, NY: Cold Spring Harbor Laboratory.

Moores, J. C., Magazin, M., DitTa, G. S. \& Leong, J. (1984). Cloning of genes involved in the biosynthesis of pseudobactin, a high-affinity iron transport agent of a plant growth-promoting Pseudomonas strain. Journal of Bacteriology 157, 53-58.
O'HoY, K. \& KRISHNAPILlaI, V. (1987). Recalibration of the Pseudomonas aeruginosa strain PAO chromosome map in time units using high-frequency-of-recombination donors. Genetics 115, 611618.

O'Sullivan, D. J., Morris, J. \& O'Gara, F. (1990). Identification of an additional ferric-siderophore uptake gene clustered with receptor, biosynthesis and fur-like regulatory genes in fluorescent Pseudomonas sp. strain M114. Applied and Environmental Microbiology 56, 2056-2064.

Simon, R., Priefer, U. \& Puhler, A. (1983). A broad host range mobilization system for in vivo genetic engineering: transposon mutagenesis in Gram negative bacteria. Biotechnology 1, 784-791.

Simon, R., O'Connell, M., Labes, M. \& Puhler, A. (1986). Plasmid vectors for the genetic analysis and manipulation of Rhizobia and other gram-negative bacteria. Methods in Enzymology 118, 640-659.

VIEIRA, J. \& Messing, J. (1982). The pUC plasmids, an M13mp7derived system for insertion mutagenesis and sequencing with synthetic universal primers. Gene 19, 259-268.

WILLETTS, N. (1984). Conjugation. Methods in Microbiology 17, 33-59.

Yanisch-Perron, C., Vieira, J. \& Messing, J. (1985). Improved M13 phage cloning vectors and host strains: nucleotide sequences of the M13mp18 and pUC19 vectors. Gene 33, 103-119. 